\title{
PENGARUH PENGUNGKAPAN CORPORATE SOCIAL RESPONSIBILITY TERHADAP FINANCIAL PERFORMANCE PADA PERUSAHAAN PERTAMBANGAN YANG TERDAFTAR DI BEI PERIODE 2012-2014
}

\author{
Monica \\ Jurusan Akuntansi/Fakultas Bisnis dan Ekonomika Universitas Surabaya \\ moniqd14n4@gmail.com
}

Drs.ec. Gregorius Rudy Antonio. M.Sc., CPA., Ak., QIA, CPMA. Jurusan Akuntansi/Fakultas Bisnis dan Ekonomika Universitas Surabaya

gregtsmart@yahoo.com

\begin{abstract}
ABSTRAK
Tujuan dari penelitian ini adalah untuk mengetahui pengaruh dari PengungkapanCorporate Social Responsibility terhadap kinerja keuangan perusahaan yang diproksikan oleh Return on Asset (ROA) dan Net Profit Margin (NPM). Penelitian ini termotivasi dari banyaknya perbedaan pada hasil penelitian sebelumnya. Penelitian ini menggunakan pendekatan kuantititatif dengan metode analisis regresi linier sederhana. Populasi yang digunakan dalam penelitian ini adalah seluruh perusahaan pertambanagan yang terdaftar di Bursa Efek Indonesia periode 2012-2014, sedangkan sampel yang digunakan dalam penelitian ini dipilih secara purposive judgment sampling menurut kriteria. Sampel yang dikumpulkan dalam penelitian ini sebanyak 99 perusahaan. Hasil penelitian ini menunjukkan pengungkapan CSR berpengaruh signifikan terhadap ROA perusahaan pertambangan, namun tidak berpengaruh signifikan terhadap NPM perusahaan pertambangan.
\end{abstract}

Kata Kunci :Corporate Social Responsibility(CSR), Return on Asset (ROA), Net Profit Margin (NPM)

\begin{abstract}
This study aimed to determine the effect of the Corporate Social Responsibility Disclosures to financial perfomances proxied by Return on Asset (ROA) and Net Profit Margin (NPM).This research established from many differences in results of previous studie and using simple linier regression analysis. The population in this study are all mining companies listed in Indonesia Stock Exchange (IDX) in 2012-2014, while samples used in this the study were selected by purposive sampling. Samples collected in this studies were 99 companies. the results show Corporate Social Responsibilities (CSR) Disclosures had significant effect Return on Asset (ROA) and had no significant effect on Net Profit Margin (NPM).
\end{abstract}

Keywords:Corporate Social Responsibility(CSR), Return on Asset (ROA), Net Profit Margin (NPM) 


\section{PENDAHULUAN}

Berdasarkan survei KPMG (2013) dapat dilihat bahwa pada tahun 2011 telah terjadi peningkatan jumlah perusahaan yang menjalankan program CSR dalam laporan tahunan mereka menjadi 95\% untuk perusahaan G250 dan 64\% bagi perusahaan N100. Peningkatan juga terjadi pada tahun 2013, dimana jumlah perusahaan N100 yang melakukan pengungkapan CSR tumbuh menjadi 71\%, walaupun terjadi penurunan sebesar 2\% pada perusahaan G250. Porter dan Krammer (2006) menyatakan bahwa perusahaan akan melakukan CSR untuk mendorong efisiensi dan meningkatkan reputasi, brand, dan kepercayaan terhadap perusahaan. Pada akhirnya, pengungkapan CSR oleh perusahaan secara tidak langsung akan berdampak pada peningkatan profit dan daya saing perusahaan. Artinya, kegiatan CSR merupakan suatu bentuk kegiatan yang merupakan implementasi tanggung jawab perusahaan terhadap kondisi sosial dan lingkungan sekitarnya sangat penting dilakukan karena dapat berdampak pada kinerja keuangan perusahaan.

Pada umumnya, kinerja keuangan menggunakan rasio keuangan sebagai pengukurannya. Rasio pengukuran yang digunakan dalam menganalisis kinerja keuangan yang sering dijumpai adalah rasio profitabilitas. Rasio profitabilitas menyediakan evaluasi menyeluruh atas kinerja perusahaan dan manajemennya. Rasio ini mengukur seberapa besar tingkat keuntungan yang dapat diperoleh perusahaan (Meythi, et al. 2011). Namun, dalam penelitian ini rasio kinerja keuangan yang digunakan adalah ROA dan NPM. ROA dipilih sebagai proksi pengukur kinerja keuangan karena ROA merupakan rasio yang menunjukkan kemampuan murni dari suatu perusahaan dalam memperoleh keuntungan. Sebab, ROA merupakan rasio yang menggambarkan efisiensi dana yang digunakan dalam perusahaan (Sugiono, 2009:80). Selain itu, Fahmi (2011) juga menyebutkan bahwa ROA merupakan earning power karena besarnya ROA mampu menggambarkan kemampuan perusahaan dalam menghasilkan keuntungan dari setiap satu rupiah asset yang digunakan.

Priyankanka dan Sukirno (2013) juga menyatakan bahwa CSR tidak berpengaruh signifikan terhadap ROA,ROE, NPM, dan tetapi berpengaruh signifikan terhadap EPS. Disisi lain, banyak pula peneliti ( Tsoutsora, 2004; 
Segun et al., 2013; Bidhari et al. ;2013; Flammer, 2013) menyatakan terdapat hubungan positif antara CSR berpengaruh signifikan terhadap kinerja keuangan. Dalam penelitian-penelitian ini, kinerja keuangan kebanyakan diproksikan pada ROA, ROE, ROI, ROS, dan NPM.

Berdasarkan pernyataan tersebut, peneliti menilai bahwa ROA cukup efisien menggambarkan kemampuan perusahaan dalam menghasilkan laba sebagai cerminan kinerja keuangan perusahaan yang baik. Selanjutnya adalah penggunaan NPM yang merupakan rasio kinerja keuangan yang menunjukkan laba perusahaan dengan membagi laba bersih terhadap total penjualan yang dimiliki oleh perusahaan. Perusahaan yang dipilih sebagai objek penelitian ini adalah perusahaan pertambangan yang terdaftar di Bursa Efek Indonesia (BEI) pada tahun 2012-2014. Hal yang mendasari peneliti menggunakan perusahaan pertambangan sebagai objek penelitian dikarenakan industri yang bergerak pada bidang pertambangan memiliki kegiatan yang langsung berpengaruh pada lingkungan sekitar, sehingga industri ini lebih dituntut untuk melakukan CSR karena dianggap merusak lingkungan.

Hal ini sebagaimana disampaikan oleh Dirjen Mineral dan Batu bara Kementerian ESDM Thamrin Sihite yang menyebutkan bahwa penerapan tanggung jawab sosial (CSR) industri pertambangan harus berupa program yang dapat mengurangi dampak kerusakan lingkungan dari usaha pertambangan (Burhani, 2012). Hal ini menunjukkan bahwa masih banyak perusahaan pertambangan yang kegiatan CSR-nya tidak berpihak pada lingkungan.

\section{METODE PENELITIAN}

Jenis penelitian ini termasuk dalam tipe penelitian kausal dengan Jenis time horizon yang digunakan adalah cross sectional. Populasi dalam penelitian ini adalah perusahaan tambang yang terdaftar di BEI periode 2012-2014. Data-data yang digunakan dalam penelitian ini adalah data sekunder. Data sekunder adalah data yang diperoleh atau dikumpulkan oleh orang yang melakukan penelitian dari sumber-sumber yang telah ada. Data sekunder yang dibutuhkan dalam penelitian ini adalah: 
a. Website BEI ( laporan tahunan masing-masing perusahaan untuk periode 2012-2014.

b. Website resmi perusahaan pertambangan, berupa detail laporan tahunan perusahaan lengkap yang tidak terdapat di website BEI untuk periode 2012-2014.

\section{Sampel dan Teknik Pengambilan Sampel}

Pengambilan sampel dalam penelitian ini dilakukan dengan menggunakan non probability sampling kategori purposive-judgetment sampling, berdasarkan kriteria yang telah ditentukan sebelumnya, adapun kriteria yang diajukan dalam penelitian ini yang digunakan untuk penilaian sampel adalah sebagai berikut:

1. Perusahaan yang menjadi sampel dalam penelitian ini adalah perusahaan pertambangan yang listed di Bursa Efek Indonesia.

2. Perusahaan yang dipilih sebagai sampel adalahperusahaan yang mengungkapkan laporkan keuangan dan laporan tahunan secara rutin tiap tahun dari tahun 2012-2014.

3. Perusahaan Pertambangan yang menjalankan pengungkapan CSR didalam Laporan Tahunan nya.

4. Mengakhiri tahun pembukuan pada bulan Desember.

\section{Variabel Dependen}

Variabel dependen dalam penelitian ini adalah Financial Performance, Rasio keuangan yang digunakan dalam penelitian ini adalah:

\section{a. Return On Asset (ROA)}

Menurut Sugiono (2009:80) rasio ini mengukur tingkat pengembalian dari bisnis atas seluruh aset yang ada, atau rasio yang menggambarkan efisiensi dana yang digunakan dalam perusahaan. Oleh karena itu, rasio ini sering disebut dengan return on investment. Berdasarkan pernyataan tersebut, peneliti menilai bahwa ROA cukup efisien menggambarkan kemampuan perusahaan dalam menghasilkan laba sebagai cerminan kinerja keuangan perusahaan yang baik. Rasio ini dapat diukur dengan formula berikut ini:

$$
\text { Eotwrn On Asset(ROA) }=\frac{\text { Laba Bersth }}{\text { Total Aset }}
$$




\section{b. NetProfit Margin (NPM)}

Rangkuti (2006:150-151), menjelaskan bahwa semakin besarnya rasio NPM suatu perusahaan menunjukkan bahwa manajemen telah bekerja secara efisien baik dalam pengelolaan produksi dan operasional maupun penjualan. Rasio ini merupakan ukuran kemampuan perusahaan untuk mengubah setiap rupiah yang diperoleh dari penjualan menjadi keuntungan bersih (net profit). Perusahaan yang memiliki rasio NPM relatif besar menunjukkan bahwa perusahaan tersebut cenderung memiliki kemampuan untuk tetap bertahan dalam kondisi sesulit apa pun. Berdasarkan uraian di atas, peneliti kemudian memilih NPM sebagai proksi dari profitabilitas. Hal ini dikarenakan NPM mampu menunjukkan kinerja manajemen baik dalam hal pengelolaan produksinya maupun hal operasionalnya. Sehingga, hal ini dapat membantu menunjukkan kepada stakeholder bahwa perusahaan yang memiliki NPM tinggi akan memiliki daya ketahanan untuk tetap eksis lebih baik. Rasio NPM ini dapat diformulasikan sebagai berikut (Harahap, 2001:304):

$$
\text { NPM }=\frac{\text { Laba bersih }}{\text { Penjualan }}
$$

\section{Variabel Independen}

Variabel independen dalam penelitian ini yaitu pengungkapan corporate social responsibility (CSR), Menurut Sembiring (2005) yang mengelompokkan informasi CSR ke dalam kategori: Lingkungan, Energi, Tenaga Kerja, Produk, Keterlibatan masyarakat, Umum.

Selanjutnya berdasarkan hasil perhitungan terhadap item CSR yang terdapat dalam laporan tahunan perusahaan tersebut dilakukan perhitungan CSD Index (CSDI) dengan rumus sebagai berikut (Haniffa dan Cooke, 2005):

$$
\operatorname{CSDI}_{\mathrm{j}}=\sum \mathrm{X}_{\mathrm{ij}}
$$

Keterangan:

$\mathrm{CSDI}_{\mathrm{j}}$ : Corporate Social Responsibility Disclosure Index perusahaan j

$\mathrm{n}_{\mathrm{j}} \quad$ : jumlah item untuk perusahaan $\mathrm{j}, \mathrm{n}_{\mathrm{j}} \leq 91$ 


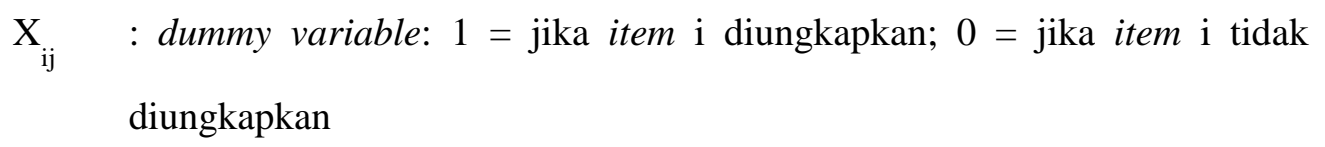

\section{Metode Pengumpulan Data}

Prosedur pengumpulan data penelitian ini adalah sebagai berikut:

a. Menentukan perusahaan yang ingin dijadikan sebagai objek penelitian yaitu perusahaan pertambangan yang terdaftar di BEI yang telah menerbitkan laporan keuangan lengkap periode 2012-2014.

b. Mencari data dokumenter laporan keuangan tahunan perusahaan pertambangan yang sesuai dengan kriteria pengambilan sampel.

c. Mencari laporan CSR atau annual report perusahaan pada situs-situs internet untuk menemukan tentang pengungkapan informasi CSR untuk masing-masing perusahaan.

\section{Analisis Data}

Pengolahan dan penganalisisan data yang telah memeuhi standar pengambilan sampel, penulis akan menggunakan Microsoft Excell 2010 dan Statistical and Service Solutions (SPSS) version 22.0 for windows.Tahapan analisis daa adalah sebagai berikut:

\section{Analisis Statistik Deskriptif}

Analisis ini digunakan untuk menganalisa data kuantitatif yang diolah menurut perhitungan dalam variabel penelitian sehingga dapat memberikan penjelasan atau gambaran mengenai kondisi perusahaan selama periode pengamatan. Analisis statistik deskriptif dilakukan dengan alat uji SPSS dan menghasilkan output antara lain berupa: mean, median, range, minimum, maksimum, standar deviasi mean, varian.

\section{Analisis Regresi Sederhana}

Teknik analisis penelitian ini menggunakan teknik analisis regresi sederhana. Menurut Efferin et al., (2008:176), regresi linier sederhana digunakan untuk melakukan prediksi terhadap suatu variabel numerik berdasarkan pada nilai dari satu atau lebih variabel yang lain. Persamaan umum regresi linier sederhana adalah sebagai berikut: 


$$
\hat{\mathrm{Y}}_{1,2}=\mathrm{a}+\mathrm{b}_{1} \mathrm{Xi}
$$

di mana:

$\hat{\mathrm{Y}}_{1}=$ nilai estimasi variabel ROA

$\hat{\mathrm{Y}}_{2}=$ nilai estimasi variabel NPM

$\mathrm{Xi}=$ nilai variabel $\mathrm{X}$ untuk observasi $\mathrm{i}$

$\mathrm{a}=$ titik potong garis regresi pada sumbu y atau nilai estimasi $\hat{y}$ bila $x=0$

$\mathrm{b}=$ koefisien variabel Corporate Social Responsibility (CSR)

\section{Rancangan Uji Hipotesis}

\section{Uji Asumsi Klasik}

Uji asumsi klasik digunakan untuk memastikan bahwa model telah memenuhi kriteria BLUE (Best Linear Unbiased Estimator). Adapun uji asumsi klasik yang digunakan dalam penelitian ini adalah sebagai berikut:

\section{a. Uji Normalitas}

Uji normalitas digunakan untuk mengetahui apakah populasi data berdistribusi normal atau tidak. Asumsi normalitas merupakan prasyarat dari prosedur statistik inferensial. Uji normalitas data dimaksudkan untuk memperlihatkan bahwa data sampel berasal dari populasi yang berdistribusi normal.

\section{Uji Hipotesis}

Pada penelitian ini, untuk menjawab hipotesis yang diajukan dalam penelitian, maka digunakan uji hipotesis yaitu uji t. Uji t dilakukan untuk mengetahui tingkat signifikansi setiap variabel bebas terhadap variabel terikat secara terpisah (Sugiyono:2007).

\section{HASIL DAN PEMBAHASAN}

\section{Statistik Deskriptif Variabel ROA}

Berdasarkan hasil pengolahan data dengan menggunakan statistik deskriptif diketahui rata-rata nilai ROA perusahaan pertambangan selama periode 20122014 sebagai berikut: 
Tabel 1

Statistik Deskriptif Variabel ROA

\begin{tabular}{|l|r|}
\hline $\mathrm{N}$ & 99 \\
\hline Minimum & $-0,27$ \\
\hline Maximum & 0,58 \\
\hline Mean & 0,0354 \\
\hline Std. Deviation & 0,10906 \\
\hline
\end{tabular}

Sumber: Data Sekunder, Diolah (2015).

Hal ini menunjukkan bahwa rentang data cukup dekat. Cukup dekatnya rentang data tersebut dapat diketahui dari selisih antara nilai maksimum dan nilai minimum yang diperoleh. Dalam penelitian ini diketahui bahwa selisih antara nilai maksimum dan nilai minimum tersebut tidak terlalu besar. Dalam penelitian ini diketahui bahwa selisih antara nilai rata-rata dengan standar deviasi tersebut tidak terlalu besar. Hasil tersebut menunjukkan bahwa data variabel ROA tergolong cukup baik.

Gambar 1

Rata-Rata Laba Bersih dan Aset Perusahaan Pertambangan 2012-2014

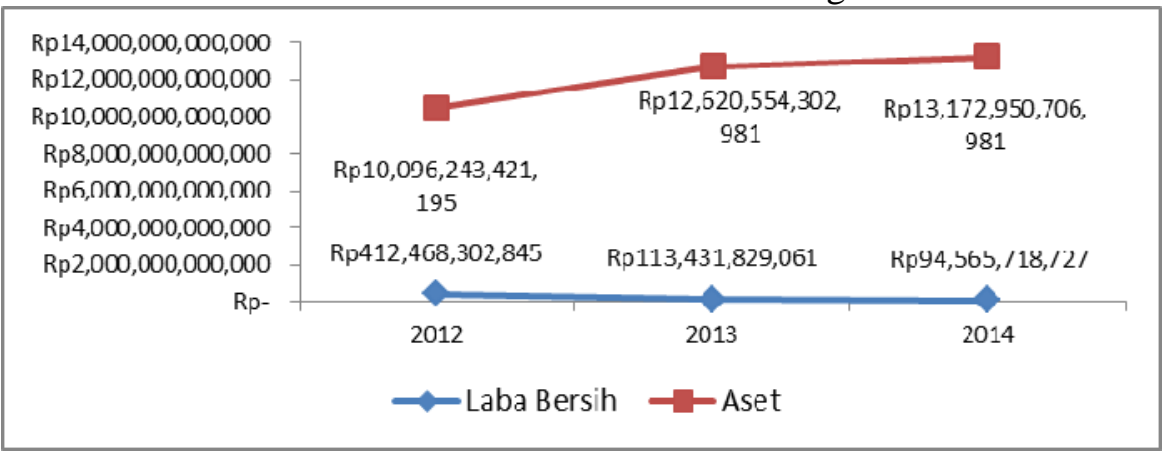

Sumber: Data Sekunder, Diolah (2015)

Gambar tersebut menunjukkan bahwa terjadi penurunan nilai laba bersih ini bisa disebabkan oleh besarnya biaya produksi dan biaya operasional perusahaan. Selain itu, nilai rata-rata penjualan per tahun yang fluktuatif juga turut mempengaruhi besaran nilai laba bersih yang dihasilkan dari tahun ke tahun.

\section{Statistik Deskriptif Variabel NPM}

Berdasarkan hasil pengolahan data dengan menggunakan statistik deskriptif diketahui rata-rata nilai NPM perusahaan pertambangan selama periode 20122014 sebagai berikut: 
Tabel 2

Statistik Deskriptif Variabel NPM

\begin{tabular}{|l|r|}
\hline $\mathrm{N}$ & 99 \\
\hline Minimum & $-9,21$ \\
\hline Maximum & 1,19 \\
\hline Mean & $-0,1086$ \\
\hline Std. Deviation & 1,08315 \\
\hline
\end{tabular}

Sumber: Data Sekunder, Diolah (2015).

Perolehan tersebut menunjukkan bahwa rentang data adalah cukup besar. Besarnya rentang data yang ada diketahui dari selisih nilai maksimum dan nilai minimum NPM yang dihasilkan. Nilai standar deviasi yang besar ini menunjukkan bahwa terjadi kesenjangan nilai NPM yang besar pada perusahaan pertambangan yang diamati selama periode 2012-2014.

Gambar 2

Rata-Rata Laba Bersih, Beban dan Penjualan Perusahaan Pertambangan Tahun 2012-2014

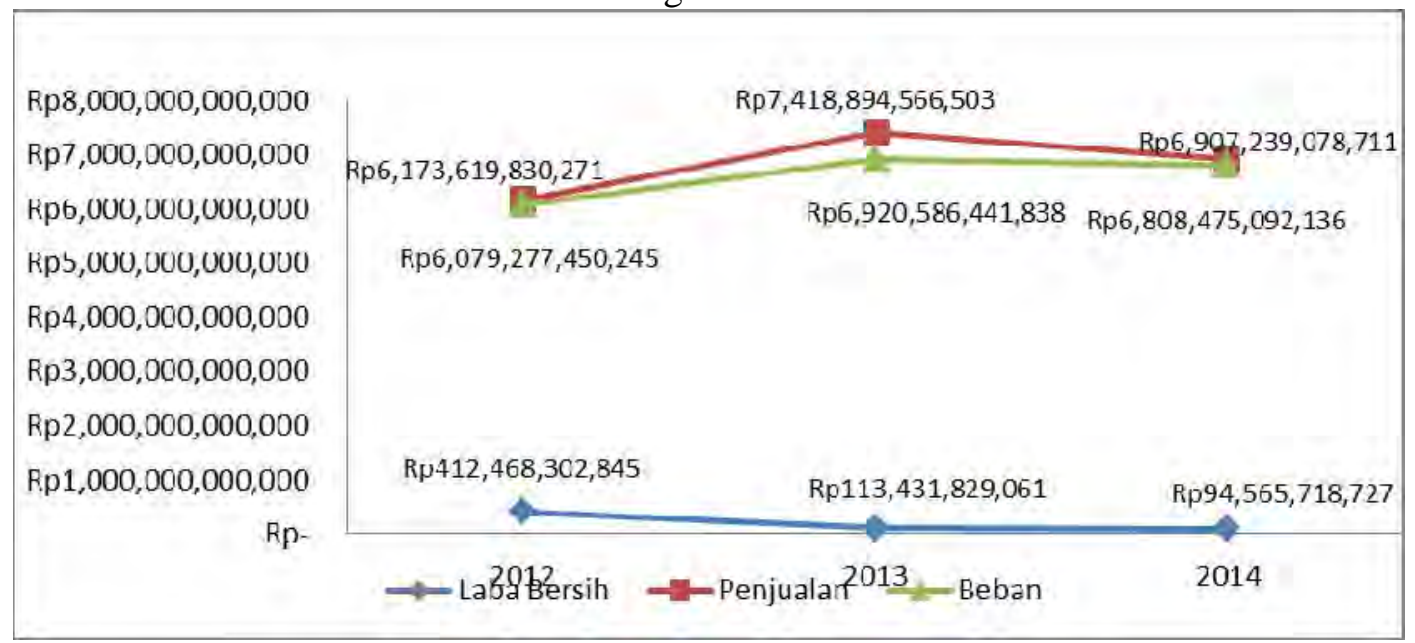

Sumber: Data Sekunder, Diolah (2015)

Gambar tersebut menunjukkan bahwa terjadi penurunan laba bersih yang terus menerus pada perusahaan pertambangan selama periode 2012-2014, walaupun kondisi penjualan dan beban yang tidak terlalu berubah secara signifikan. Hal ini menunjukkan bahwa perusahaan pertambangan sampai pada level tertentu, tidak efisien dalam mengelola beban-beban yang dimilikinya. 


\section{Statistik Deskriptif Variabel Pengungkapan CSR}

Berdasarkan hasil pengolahan data dengan menggunakan statistik deskriptif diketahui rata-rata nilai CSDI perusahaan pertambangan selama periode 20122014 sebagai berikut:

Tabel 3

Statistik Deskriptif Variabel CSR

\begin{tabular}{|l|r|}
\hline $\mathrm{N}$ & 99 \\
\hline Minimum & 0,03 \\
\hline Maximum & 0,75 \\
\hline Mean & 0,2248 \\
\hline Std. Deviation & 0,14921 \\
\hline
\end{tabular}

Sumber: Data Sekunder, Diolah (2015).

Perolehan tersebut menunjukkan bahwa rentang data yang terdapat pada variabel CSR tidak terlalu besar. Sehingga dapat diketahui bahwa kesenjangan penerapan CSR antar perusahaan pertambangan tidak terlalu besar.

\section{Uji Asumsi Klasik}

Hasil uji normalitas data akan disajikan berdasarkan model regresi linier sederhana yang dibangun peneliti. Adapun hasil uji normalitas data penelitian yang telah dilakukan oleh peneliti adalah sebagai berikut:

\section{Pengaruh Pengungkapan CSR terhadap ROA}

Uji normalitas data yang digunakan dalam penelitian ini adalah uji normalitas data dengan melihat normal probability plot dan uji Kolmogorof-Smirnov.

Berikut adalah uji Kolmogorof-Smirnov dengan menggunakan bantuan SPSS for windows version 22.0.

Tabel 4

Hasil Uji Kolmogorof-Smirnov Model Regresi (Pengaruh CSR terhadap ROA)

\begin{tabular}{|l|r|}
\hline & \multicolumn{2}{|c|}{$\begin{array}{c}\text { Unstandardized } \\
\text { Residual }\end{array}$} \\
\hline $\mathrm{N}$ & 99 \\
\hline Kolmogorov-Smirnov Z & 1,263 \\
\hline Asymp. Sig. (2-tailed) & 0,082 \\
\hline
\end{tabular}

Sumber: Data Sekunder, Diolah (2015) 
Tabel 4 menunjukkan bahwa berdasarkan uji normalitas maka model regresi memenuhi uji asumsi normalitas, karena model regresi yang dihasilkan memiliki nilai Kolmogorof-Smirnov sebesar 1,263 pada tingkat probabilitas > 0,05, yaitu 0,082. Artinya adalah bahwa residual model regresi berdistribusi normal.

\section{Pengaruh Pengungkapan CSR terhadap NPM}

Berikut adalah pengujian Kolmogorov-Smirnov data dengan menggunakan bantuan SPSS for windows version 22.0.

Tabel 5

Hasil Uji Kolmogorof-Smirnov Model Regresi (Pengaruh Pengungkapan CSR terhadap NPM)

\begin{tabular}{|l|r|}
\hline & \multicolumn{2}{|c|}{$\begin{array}{l}\text { Unstandardized } \\
\text { Residual }\end{array}$} \\
\hline $\mathrm{N}$ & 99 \\
\hline Kolmogorov-Smirnov Z & 3,324 \\
\hline Asymp. Sig. (2-tailed) & 0,000 \\
\hline
\end{tabular}

Sumber: Data Sekunder, Diolah (2015)

Tabel tersebut menunjukkan bahwa berdasarkan uji normalitas maka model regresi memenuhi uji asumsi normalitas, karena model regresi yang dihasilkan memiliki nilai Kolmogorof-Smirnov sebesar 3,324 pada tingkat probabilitas < 0,05, yaitu 0,000. Artinya adalah bahwa residual model regresi tidak berdistribusi normal.

Untuk memenuhi asumsi normalitas data, maka langkah statistik yang dilakukan oleh peneliti adalah melakukan transformasi data.Transformasi data yang digunakan dalam penelitian ini adalah $\log 10$ pada data penelitian.Setelah data ditransformasi, kemudian data hasil transformasi tersebut diolah kembali untuk uji normalitas.Adapun hasil uji normalitas data yang sudah ditransformasi $\log 10$ tersebut dapat dilihat pada tabel 6.

Tabel 6

Hasil Uji Kolmogorof-Smirnov Model Regresi (Pengaruh Pengungkapan CSR terhadap LogNPM)

\begin{tabular}{|l|r|}
\hline & \multicolumn{2}{|c|}{$\begin{array}{lr}\text { Unstandardized } \\
\text { Residual }\end{array}$} \\
\hline $\mathrm{N}$ & \\
\hline Kolmogorov-Smirnov Z & 0,654 \\
\hline Asymp. Sig. (2-tailed) & 0,786 \\
\hline
\end{tabular}

Sumber: Data Sekunder, Diolah (2015) 
Tabel 4.10 menunjukkan bahwa berdasarkan uji normalitas maka model regresi memenuhi uji asumsi normalitas, karena model regresi yang dihasilkan memiliki nilai Kolmogorof-Smirnov sebesar 0,654 pada tingkat probabilitas > 0,05 , yaitu 0,786. Artinya adalah bahwa residual model regresi berdistribusi normal.

\section{Uji Hipotesis}

Berdasarkan model regresi yang ada dalam penelitian ini adalah regresi linier sederhana, maka uji hipotesis yang digunakan adalah uji hipotesis dengan uji t (parsial). Adapun hasil uji t (parsial) yang dilakukan dalam penelitian ini adalah sebagai berikut:

Tabel 7

Hasil Uji t (Parsial)

\begin{tabular}{|l|c|c|c|}
\hline \multicolumn{1}{|c|}{ Model } & B & T & Sig. \\
\hline Pengungkapan CSR Terhadap ROA & \multicolumn{2}{l|}{} \\
\hline $1 \quad$ (Constant) & $-0,011$ & $-0,587$ & 0,558 \\
\hline CSDI & 0,207 & 2,916 & 0,004 \\
\hline \multicolumn{2}{|l|}{ Pengungkapan CSR Terhadap NPM } & $-4,467$ & 0,000 \\
\hline $1 \quad$ (Constant) & $-0,930$ & 1,623 & 0,109 \\
\hline LogCSDI & 0,474 &
\end{tabular}

Sumber: Data Sekunder, Diolah (2015)

Berdasarkan sajian data di atas, maka dapat diketahui bahwa pada model pertama yaitu pengaruh pengungkapan CSR terhadap ROA diketahui memperoleh nilai t hitung sebesar 2,916 dengan taraf signifikansi sebesar $0,004<0,05$. Perolehan nilai signifikansi tersebut menunjukkan bahwa nilai signifikansi yang diperoleh lebih kecil dari 0,05. Sehingga dapat dinyatakan bahwa pengungkapan CSR berpengaruh positif dan signifikan terhadap ROA perusahaan pertambangan.

Sedangkan pada model regresi yang kedua yaitu pengaruh pengungkapan CSR terhadap NPM, diketahui memperoleh nilai t hitung sebesar 1,623 dengan taraf signifikansi sebesar 0,109 > 0,05. Perolehan nilai signifikansi tersebut juga lebih besar dari 0,05, sehingga dapat dinyatakan bahwa pengungkapan CSR tidak berpengaruh signifikan terhadap NPM perusahaan pertambangan. 


\section{KESIMPULAN DAN SARAN}

\section{a. Kesimpulan}

Berdasarkan hasil olah data yang dilakukan dalam penelitian ini, dan uji hipotesis yang telah diuraikan pada bab sebelumnya, maka temuan dari penelitian ini dapat diringkas sebagai berikut:

1. Pengungkapan Corporate social responsibility (CSR) berpengaruh positif dan signifikan terhadap ROA perusahaan pertambangan, dan berjalan searah dengan penelitian Flammer (2013) yang menyatakan pengungkapan CSR berpengaruh signifikan terhadap kinerja keuangan yang diproksikan lewat ROA.

2. Pengungkapan Corporate social responsibility (CSR) tidak berpengaruh signifikan terhadap NPM perusahaan pertambangan, hasil penelitian ini berjalan tidak searah dengan penelitian Flammer (2013) yang menyatakan pengungkapan CSR berpengaruh signifikan terhadap kinerja keuangan yang diproksikan lewat NPM.

\section{b. Saran}

Berdasarkan temuan dalam penelitian ini yang sudah diringkas di atas, maka saran yang dapat diajukan dalam penelitian ini adalah sebagai berikut:

1. Bagi Perusahaan Pertambangan

Pada penelitian ini menemukan bahwa ROA dan NPM perusahaan pertambangan yang diteliti terus mengalami penurunan dan dalam posisi yang cukup rendah, untuk dapat meningkatkan laba perusahaan, maka sebaiknya perusahaan pertambangan lebih efektif dan efisien dalam mengatur pengeluaran perusahaan. Pelaksanaan pengungkapan CSR sebaiknya dilakukan sesuai dengan ketentuan yang berlaku tanpa berlebihan. Sehingga laba yang diperoleh tidak habis dialokasikan pada pengungkapan CSR.

\section{Bagi Investor}

Penting bagi para investor untuk tetap memperhatikan aspek laba bersih yang dihasilkan oleh suatu perusahaan untuk mengukur profitable suatu perusahaan. 
ROA dan NPM dapat menjadi acuan para investor dalam mengetahui tingkat profitable dari suatu perusahaan. Sehingga para investor dapat dengan tepat menanamkan modalnya menjadi suatu investasi yang menguntungkan.

3. Bagi Penelitian Selanjutnya

Bagi penelitian selanjutnya yang menggunakan tema yang sama, diharapkan dapat menambah variabel penelitian maupun tahun penelitian. Serta penelitian selanjutnya dapat menggunakan objek perusahaan sektor lainnya. Supaya hasil yang diperoleh nantinya dapat saling melengkapi. Mengingat temuan dari penelitian ini juga tidak dapat digeneralisasikan pada perusahaan dengan sektor yang berbeda.

\section{DAFTAR PUSTAKA}

Bidhari, Sandhika C., U. Salim, \& S. Aisjah. 2013. Effect of Corporate Social Responsibility Information Disclosure on Financial Performance and Firm Value in Banking Industry Listed at Indonesia Stock Exchange. European Journal of Business and Management, Vol.5, No.18, 2013, hal. 39-40.

Burhani, R. 2012.CSR Tambang Diharapkan Fokus Kurangi DampakLingkungan.

http://www.antaranews.com/berita/321240/csr-tambang-diharapkan-fokuskurangi-dampak-;lingkungan, (diakses7 September 2015).

Fahmi, Irham. 2011. Analisis Kinerja Keuangan. Badung: Alfabeta.

Haniffa, R.M., \& T.E. Cooke. 2005. The Impact of Culture and Governance on Corporate Social Reporting.Journal of Accounting and Public Policy Vol.24.

Harahap, Sofyan Syafri. 2001. Teori Akuntansi. Jakarta: PT Raja Grafindo Persada.

KPMG, I. 2013. The KPMG Survey Of Corporate Responsibility Reporting 2013.www.home.kpmg.com/xx/en/home/insight/2013/12/kpmg-surveycorporate-responsibility-reporting-2013.html (diakses tanggal 5 Juli 2013).

Meythi, Tan Kwang En, \& Linda R. 2011. Pengaruh Likuiditas \& Profitabilitas Terhadap Harga Saham Perusahaan Manufaktur yang Terdaftar di Bursa Efek Indonesia. Jurnal Bisnis Manajemen \& Ekonomi, Volume 10, No. 2, Mei 2011, hal. 2671-2684. 
Porter, M. E. \& Kramer, M. R. 2006. Strategy And Society, The Link Between Competitive Advantage And Corporate Social Responsibility. Harvard Business Review, Vol. 82 No.12, hal 78-79.

Rangkuti, F. 2006. Business Plan: Teknik Membuat Perencanaan Bisnis \& Analisis Kasus. Jakarta: Gramedia Pustaka Utama.

Sugiyono. 2007. Statistika Untuk Penelitian. Bandung: Alfabeta.

Segun, A., Fagemi, T. O. \& Uwuigbe, O.R. 2013. The Impact of Corporate Social Responsibility Expenditure On Firm Performance and Firm Vale of Nigerian Banks. Advances in Management, Volume 12, No. 1 (2013), hal. 1-12.

Sugiono, Arief. 2009. Manajemen Keuangan Untuk Praktisi Keuangan. Jakarta: Grasindo.

Tsoutsora, M. 2004. Corporate Social Responsibility and Financial

Performance. Haas School of Business, University of California at Berkeley, Applied Financial Project.

http://responsiblebusinessnew.haas.berkeley.edu/documents/FinalPaperonCSR_PDFII.pdf (diakses 25 Juli 2015) 